\title{
SIKAP HIDUP WANITA JAWA DALAM NOVEL BEKISAR MERAH DAN NOVEL MIDAH SI MANIS BERGIGI EMAS
}

\author{
Arif Setiawan \\ Program Studi Pendidikan Bahasa dan Sastra Indonesia \\ Universitas Muhammadiyah Malang \\ arifsetiawan1988@gmail.com
}

\begin{abstract}
Abstrak: Penelitian ini mendeskripsikan sikap hidup wanita Jawa dalam novel Bekisar Merah karya Ahmad Tohari dan Midah Si Manis Bergigi Emas karya Pramoedya Ananta Toer yang dikaitkan dengan kehidupan sehari-hari, sehingga menjadi refleksi dalam bersikap dan bertindak terhadap Tuhan, diri sendiri, dan orang lain. Penelitian ini menggunakan pendekatan sosiologi sastra, jenis peneletian ini adalah kualitatif. Metode yang digunakan dalam penelitian ini adalah analisis deskriptif. Sumber data berupa novel Bekisar Merah karya Ahmad Tohari dan novel Midah Si Manis Bergigi Emas karya Pramoedya Ananta Toer. Data dalam penelitian ini berupa satuan cerita dari kutipan-kutipan yang merepresentasikan sikap hidup wanita Jawa. Hasil penelitian menggambarkan sikap hidup wanita Jawa dalam kehidupan beragama, sikap hidup wanita Jawa terhadap diri sendiri, serta sikap hidup wanita Jawa dalam lingkup bermasyarakat.
\end{abstract}

Kata kunci: sikap hidup, wanita Jawa

\begin{abstract}
This study describes the attitude of Javanese women living in the novels Bekisar Merah by Ahmad Tohari and Midah Si Manis Bergigi Emas by Pramoedya Ananta Toer work associated with everyday life, so it becomes a reflection of behaving and acting against God, themselves, and others. This study uses the literary sociology approach which is qualitative in nature. The method used in this study is descriptive analysis. Sources of data are the novels Red Bekisar by Ahmad Tohari and Midah Si Manis Bergigi Emas by Pramoedya Ananta Toer. The data are story units quoted in accordance with the purpose and focus of the study. The findings are: first of all, the attitudes Javanese women in their religious life; secondly, the attitude of Javanese women toward themselves; and thirdly, the attitude of Javanese women in their community.
\end{abstract}

Key words: attitude, Javanese women

\section{PENDAHULUAN}

Karya sastra menampilkan gambaran kehidupan suatu masyarakat dan karya sastra mampu memberikan makna tertentu pada pembaca. Novel sebagai salah satu jenis karya sastra hadir dari tulisan pengarang yang merupakan bagian dari masyarakat. Melalui karyanya pengarang mengajak pembaca untuk menghayati dan menangkap fenomena kehidupan yang dijalankan oleh tokoh-tokoh dalam cerita. Karya sastra dapat dipahami dengan jelas jika tidak dipisahkan dengan lingkungan sosial yang melatari lahirnya karya sastra tersebut. Menurut Hawkes (dalam Pradopo 1990: 120) karya sastra merupakan sebuah struktur. Artinya sastra itu mempunyai sistem yang saling timbal balik, saling menentukan. Jadi kesatuan unsur-unsur dalam karya sastra berupa kumpulan hal-hal yang saling terkait satu sama lainya, sehingga makna karya sastra ditentukan oleh hubungan dengan semua unsur lainnya yang terkandung dalam struktur tersebut.
Sastra merupakan bagian dari kebudayaan. Mengkaji kebudayaan tidak dapat melihatnya sebagai sesuatu yang statis, yang tidak berubah, tetapi merupakan sesuatu yang dinamis, yang senantiasa berubah. Hubungan antara kebudayaan itu sendiri menurut Antropologi adalah cara, suatu kumpulan manusia atau masyarakat mengadakan sistem nilai, yaitu berupa aturan yang menentukan suatu benda atau perbuatan yang lebih tinggi nilainya dari yang lain. Kebanyakan para ahli Antropologi melihat kebudayaan itu merupakan satu kesatuan, keseluruhan, di mana sistem sosial itu sendiri adalah sebagian dari kebudayaan. Singkatnya kebudayaan itu sendiri dikatakan sebagai cara hidup yaitu bagaimana suatu masyarakat itu mengatur hidupnya (Semi, 1989: 54).

Novel merupakan karya yang mengangkat permasalahan yang tidak pernah lepas dari keterkaitan dengan realitas kehidupan. Masalah dan permasalahan yang ada di sekitar tokoh, diimajinasikan dan diceritakan sesuai dengan pikiran pengarang (Goldman dalam Faruk, 1999: 18). Kebudayaan merupakan 
suatu unsur yang tidak pernah lepas dari sebuah novel. Novel Bekisar Merah karya Ahmad Tohari dan novel Midah Si manis Bergigi Emas karya Pramoedya Ananta Toer, juga menggambarkan kebudayaan Jawa di dalamnya. Ini tidak terlepas dari latar belakang kedua pengarang yaitu Ahmad Tohari dan Pramoedya Ananta Toer yang berasal dari Jawa. Latar belakang pengarang inilah yang mendasari penggambaran kedua tokoh (Lasi dan Midah) dalam novel lekat sekali dengan budaya Jawa.

Suku bangsa Jawa, adalah suku bangsa terbesar di Indonesia. Mereka berasal dari pulau Jawa dan terutama di provinsi Jawa Tengah dan Jawa Timur. Suku bangsa Jawa sebagian besar menggunakan bahasa Jawa dalam bertutur sehari-hari. Bahasa Jawa merupakan bahasa yang sangat sopan dan menghargai orang yang diajak bicara, khususnya bagi orang yang lebih tua, bahasa Jawa juga mempunyai arti yang luas (Suseno, 1988: 11). Orang Jawa terkenal sebagai suku bangsa yang sopan dan halus, tetapi mereka juga terkenal sebagai suatu suku bangsa yang tertutup dan tidak mau berterus terang.

Masyarakat Jawa juga terkenal akan pembagian golongan-golongan sosialnya. Masyarakat Jawa terbagi menjadi tiga kelompok yaitu; kaum santri, abangan dan priyayi. Kaum santri adalah penganut agama Islam yang taat, kaum abangan adalah penganut Islam secara nominal atau penganut Kejawen, sedangkan kaum priyayi adalah kaum bangsawan (Suseno, 1988: 13). Agama yang dianut oleh sebagian besar suku Jawa adalah Islam kemudian Kristen, Katholik, Hindu, dan Budha. Ada pula agama kepercayaan suku Jawa yang disebut sebagai agama Kejawen. Kepercayaan ini terutama berdasarkan kepercayaan animisme dengan pengaruh HinduBuddha yang kuat. Masyarakat Jawa terkenal akan sifat sinkretisme. Semua budaya luar diserap dan ditafsirkan menurut nilai-nilai Jawa, sehingga kepercayaan seseorang Kadangkala.menjadi.kabur.

Wanita, dalam konsep budaya Jawa berarti “Wani Ditata" (berani untuk ditata/diatur). Hanya untuk dibentuk sebagai pribadi pengabdi yang bisa ditentukan/ ditata oleh sang suami. Memakai kebaya, kain (Jarik), dan sanggul, berkulit sawo matang dengan wajah pribumi yang eksotis, lemah lembut dalam bertutur kata, mengalah, nrimo (menerima), dan mengabdi, seperti itulah wanita Jawa digambarkan. Adanya batasan ruang gerak seorang wanita Jawa. yang. hanya. terikat. pada. norma. dan. adat. istiadat,. menjadikan mereka kaum.yang/semakin/lemah/posisinya.

Dalam budaya Jawa, wanita sejati adalah wanita yang bisa mematuhi suami, menjadi pengurus rumah tangga, dan mampu melahirkan serta mendidik anak. Tugas wanita sudah dipatenkan dengan orientasi yang hanya seputar dapur, kasur, dan sumur. Konsep swargo nunut neraka katut (surga ikut suami neraka juga ikut atau semua baik buruknya itu ditentukan oleh suami) semakin mengukuhkan wanita dalam posisi yang lemah.

Dalam kehidupan masyarakat Jawa terdapat sikap hidup yang digunakan untuk membentengi diri agar selalu tercipta keadaan yang selaras antara hubungan dengan Tuhan sebagai sang Pencipta, antara hubungan dengan orang lain dalam bermasyarakat, dan diri sendiri agar memiliki kepribadian yang baik. Sikap hidup yang dimiliki oleh orang Jawa merupakan perwujudan tingkah laku yang berasal dari pemahaman terhadap gejala-gejala kehidupan dan pengalamanpengalaman dalam kehidupan sehari-hari. Sikap hidup merupakan suatu perbuatan yang berdasarkan pada pendirian (pendapat atau keyakinan) dalam diri seseorang. Sikap menurut Koentjaraningrat (1984: 44), disebut pula "attitude”. Sikap merupakan kecendrungan untuk bertindak dan bereaksi terhadap rangsangan. Oleh karena itu, sikap tidak dapat langsung terlihat, akan tetapi harus ditafsirkan terlabih dahulu sebagai tingkah laku yang masih tertutup. Sikap selalu berhubungan dengan suatu objek, dan biasanya sikap selalu memberikan penilaian yang dapat berupa kemauan untuk menerima dan ketegasan untuk menolak. Jadi sikap selalu tergantung oleh objek yang ada. Suseno (1988: 141) mengatakan bahwa sikap dapat dilihat berdasarkan interaksi seseorang dalam kehidupan sehari-hari. Sikap hidup merupakan bentuk nyata dari pandangan hidup. Koentjaraningrat (1984: 24) mengungkapkan bahwa orang Jawa dalam bersikap selalu menyesuaikan dengan tiga konsep hidup mereka yaitu; (1) sikap hidup dalam kehidupan beragama, (2) sikap hidup dalam kehidupan bermasyarakat, dan (3) sikap hidup manusia dengan dirinya sendiri.

Sebagai manusia semestinya menyadari bahwa dirinya adalah makhluk ciptaan Tuhan. Dalam masyarakat Jawa mempunyai satu peringatan "jangan melupakan asalmu”, yang bertujuan untuk mengingatkan bahwa setiap individu adalah cpitaan Tuhan. Sikap hidup dalam kehidupan beragama mencakup eling (ingat), pracaya (percaya), mituhu (percaya kepadanya) (Mulder, 1996: 46).

Suseno (1988: 141) mengatakan eling adalah ingat akan Allah. Manusia sebagai mahluk ciptaan Tuhan hendaknya selalu mengingat akan Allah sebagai Sang pencipta. Hal ini ditujukan agar manusia selalu mengingat Allah di mana dan kapan pun ia berada. Pracaya adalah percaya, orang hendaknya selalu mempercayakan diri pada bimbingan Yang 
Ilahi. Sebagai manusia, kita selalu memiliki keinginan yang banyak dan bermacam-macam. Hal ini terkadang membuat manusia melupakan segala tata cara untuk memenuhi keinginan tersebut. Dalam bersikap hendaknya manusia selalu mempercayakan kepada Allah untuk selalu membimbing menuju jalan yang benar (Suseno, 1988: 141). Mituhu adalah percaya kepadanya. Sebagai manusia pastinya memiliki segala keinginan dan rencana, harus disadari bahwa manusia memang bisa merencanakan segala sesuatu tapi yang menentukan semuanya adalah Allah. Oleh karena itu kita hendaknya mempercayakan segala sesuatunya kepada-Nya.

Manusia tercipta sebagai mahluk sosial, tidak ada satu pun manusia yang bisa hidup sendiri. Untuk melakukan hal sekecil apapun kita tetap membutuhkan bantuan dari orang lain. Dalam kehidupan bermasyarakat manusia hendaknya mampu menjaga prinsip hidup rukun. Sikap hidup dalam kehidupan bermasyarakat meliputi isin (malu), sungkan (segan), wedi (takut), ethok-ethok (berpura-pura) (Mulder, 1996: 50).

Menurut Suseno (1988: 65) sungkan adalah malu dalam arti yang lebih positif. "Rasa hormat yang sopan terhadap atasan atau sesama yang belum dikenal". Sebagai pengekangan halus terhadap kepribadian sendiri demi hormat terhadap pribadi lain. Sungkan adalah rasa malu positif yang dirasakan berhadapan dengan atasan. Tatanan ini lebih mengarah pada pengekangan rasa malu yang lebih bersifat positif, jadi pada dasarnya orang tua selalu menanamkan pada anaknya untuk memiliki rasa segan kepada setiap orang yang belum dikenalnya. Orang tua hendaknya mengajarkan pada anak untuk lebih banyak lagi mengenal adat istiadat, tatanan dan sopan santun yang mengatur hubungan dalam kehidupan bermasyarakat.

Wedi adalah berarti takut, baik sebagai reaksi terhadap ancaman fisik maupun sebagai rasa takut terhadap akibat kurang enak suatu tindakan. Kefasihan dalam menggunakan sikap-sikap hormat yang tepat dikembangkan pada orang Jawa sejak kecil melalui pendidikan keluarga. Aplikasinya, orang Jawa selalu menanamkan rasa takut kepada orang yang dihormati, yang lebih tua dan asing bagi mereka. Diharapkan nantinya dalam bermasyarakat anak tersebut mampu membawa dirinya dan menempatkan sendiri pada lingkungan masyarakat yang lebih luas (Suseno, 1988: 63).

Isin adalah berarti malu, juga dalam arti malumalu, merasa bersalah, dan sebaginya. Sikap malu sebisa mungkin di dalam masyarakat Jawa sudah tertanam/dibiasakan sejak kecil, dengan sikap malu nantinya manusia tersebut mampu menjaga dirinya sendiri di depan orang. Dalam kepribadian Jawa, belajar isin atau mengerti malu merupakan langkah pertama ke arah kepribadian Jawa yang matang. Dengan mengembangkan rasa malu, setiap orang Jawa biasanya tidak kelihatan terganggu dengan adanya segala macam aturan sopan santun, melainkan bahkan nampak lebih santai bergaul dalam kerangka itu. kiranya tidak berlebihan untuk mengatakan bahwa ketakutan terhadap rasa isin/malu merupakan salah satu motivasi terkuat bagi orang Jawa untuk menyesuaikan kelakuannya dengan norma-norma masyarakat.

ethok-ethok adalah bahwa di luar lingkungan keluarga inti orang tidak akan memperlihatkan perasaan-perasaan yang sebenarnya. Itu terutama berlaku tentang perasaan-perasaan negatif, walaupun seseorang diliputi kesedihan yang mendalam, ia diharapakan tersenyum. Apabila kita mendapatkan kunjungan orang yang kita benci, kita harus tetep kelihatan gembira. Banyak orang Jawa yang menjadi juara dalam melakukan seni berpura-pura ini, hal ini ditujukan agar selalu tercipta keakraban dalam hubungan antar orang dalam kehidupan sehari-hari (Suseno, 1988: 43).

Tidak bisa dipungkiri walaupun manusia terlahir sebagai mahluk sosial, tetap saja masih ada sifat individual dalam diri setiap manusia. Sifat individu dalam diri manusia ada yang bersifat positif dan ada yang bersifat negatif. Terkadang sifat individu manusia lebih mengarah kepada yang negatif. Oleh karena itu, hendaknya dalam bersikap dengan diri sendiri hendaknya manusia tetap rila (rela), nrima (menerima), dan sabar (sabar). Diharapkan dengan bersikap menerima, rela dan sabar, nantinya akan memberikan kebahagian pribadi pada individu itu sendiri.

Rila adalah kesanggupan untuk melepaskan, sebagai kesediaan untuk melepaskan hak milik, kemampuan-kemampuan dan hasil-hasil pekerjaan sendiri apabila itulah yang menjadi tuntutan tanggung jawab atau nasib. Banyak orang Jawa mengatakan rila hampir sama dengan nrima, akan tetapi pada kenyataannya sangat berberda. Bila dilihat lebih lanjut rila merupakan kesanggupan dalam melepaskan segalanya yang kita miliki demi tanggung jawab. Sedangkan nrima menerima segala yang mendatangi kita tanpa protes dan banyak mengeluh.

Nrima adalah menerima segala apa yang mendatangi kita, tanpa protes dan pemberontakan. Sebagai manusia harus secara sadar mengikuti rel dari takdirnya, yang betapapun tidak dapat dihindari olehnya. Ini tidak berarti bahwa orang tidak harus berusaha mencapai sebaik-baiknya, sebab orang hanya bisa mengetahui hasil dari nasibnya dengan 
akibat dari perbuatannya. Mulder (1996: 25) menyatakan kalau nrima berarti tahu tempatnya sendiri, percaya pada nasib sendiri dan berterima kasih kepada “Tuhan” karena ada kepuasaan dalam memenuhi apa yang menjadi bagiannya dengan kesadaran bahwa semuanya telah ditetapkan oleh “Tuhan” tanpa bisa kita mengetahuinya.

Menurut Kamus Besar Bahasa Indonesia (2006: 588) sabar adalah tidak meledak-ledak emosinya, tidak lekas marah, tahan menghadapi cobaan; tabah; tenang. Dalam setiap kehidupan, manusia tidak pernah lepas dari cobaan. Tentunya cobaan tersebut untuk mengukur tingkat kesabaran manusia itu sendiri dalam menjalaninya. Dengan sikap sabar segala sesuatunya pasti akan lebih tertata. Hal inilah yang selalu ditekankan oleh para nenek moyang, agar dalam menjalani, mengambil serta menentukan keputusan tidak tergesa-gesa dan lebih mengutamakan sabar, dengan bersabar maka pikiran manusia dapat menata satu demi satu apa yang hendak dilakukan, dan tidak mendahulukan emosi yang bersifat sesaat. Apabila manusia mampu melakukan semua itu, maka akan memberikan ketentraman dan ketenangan batin dalam menjalani setiap kehidupan di dunia.

\section{METODE}

Penelitian ini menggunakan pendekatan sosiologi sasatra, Adapun jenis penelitian ini adalah kualitatif. Metode yang digunakan adalah metode deskriptif analisis. Sumber data penelitian ini adalah novel Bekisar Merah karya Ahmad Tohari dan novel Midah Si Manis Bergigi Emas karya Pramoedya Ananta Toer. Data dalam penelitian berupa satuan cerita dan kutipan-kutipan dalam novel yang relevan dengan tujuan penelitian. Teknik pengumpulan data yaitu membaca secara cermat dan berulang, mengidentifikasi, mencatat atau memberi kode, memeriksa atau menyeleksi, dan memasukan data. Analisis datanya dilakukan dengan cara (1) mencari hubungan antar data, (2) interpretasi, (3) analisis data, (4) menyimpulkan.

\section{HASIL DAN PEMBAHASAN}

Penelitian ini mencoba untuk mengungkapkan sikap hidup dua tokoh utama, Lasi dalam novel Bekisar Merah karya Ahmad Tohari dan Midah dalam novel Midah Si Manis Bergigi Emas karya Pramoedya Ananta Toer, sebagai wanita Jawa. Hal ini tidak terelpas dari latar belakang kedua pengarang yang berasal Jawa, sehingga ideologi meraka secara tidak langsung tergambar dalam tokoh yang mereka tuliskan ke dalam novel. Kedua tokoh tersebut digambarkan memiliki sikap hidup pada masing- masing karakter yang mana sikap tersebut disesuaikan dengan konsep hidup Jawa yaitu, yaitu:(1) sikap hidup dalam kehidupan beragama, (2) sikap hidup dalam kehidupan bermasyarakat, dan (3) sikap hidup manusia dengan dirinya sendiri Koentjaraningrat (1984: 24). Pada pembahasan ini akan diungkapkan bagaimana sikap hidup wanita Jawa dalam kehidupan sehari-hari yang terdapat dalam novel Bekisar Merah karya Ahmad Tohari dan novel Midah Si Manis Bergigi Emas karya Pramoedya Ananta Toer.

\section{Sikap Hidup Tokoh Lasi dalam novel Bekisar Merah Karya Ahmad Tohari}

\section{Sikap Hidup Tokoh Lasi dalam Kehidupan Beragama yang meliputi (eling "ingat", pracaya "percaya", dan mituhu "percaya kepadanya")}

Kesadaran bahwa setiap individu bergantung dari Yang Ilahi merupakan salah satu latar belakang setiap orang Jawa. Orang Jawa sering mengatakan “jangan pernah melupakan asalmu” sebagai peringatan pada setiap individu, sehingga membentuk individu yang selaras dengan agama. Berkaitan dengan sikap hidup yang meliputi kehidupan beragama, berikut kutipan data yang menunjukkan sikap eling (ingat).

"Aku boleh dibilang punya semuanya kemudahan untuk melakukan hal itu. Bahkan sudah kubilang, suamiku pun mengizinkannya. Tetapi,. semua. itu.terasa.ganjil.Jat,.dan.aku.masih.eling”

\section{(BM/2005/hal:295/L/SH/El-1)}

Setelah menikah dengan Handarbeni kebutuhan lahir Lasi memang tercukupi, tapi kebutuhan batin terasa kurang tercukupi karena Handarbeni tidak bisa memuaskan Lasi, maka dia memberikan izin dan akan menyediakan serta mencarikan lelaki sesuai dengan keinginan Lasi. Kutipan di atas menggambarkan bahwa ada rasa khawatir akan dosa yang akan ditanggung nantinya, dalam dialog tersebut diperlihatkan sikap eling (ingat) Lasi. Lasi merasa Gusti Allah telah mendengarkan doanya, dan itu semua telah terbukti. Seperti kutipan novel berikut ini.

"Oh betul gusti Allah ora sare, bisik Lasi untuk dirinya sendiri. Akhirnya. kang. Darsa. sembuh. karena.welas asih-Nya"

\section{(BM/2005/hal:68/L/SH/M-1)}

Lasi merasa segala doa, usaha dan kerja kerasnya selama ini untuk merawat Darsa telah didengarkan oleh Gusti Allah. Darsa kini telah sembuh dan pulih kembali seperti dulu kala. Dan Gusti Allah memang ora sare, berkat welas asih-Nya kang Darsa sembuh, kata-kata itu yang terus terucap dari mulut Lasi. Lasi masih percaya apa yang selama ini menjadi keinginannya 
pasti akan terwujud bila Gusti Allah berkehendak. Ini ditunjukkan pada kutipan di bawah ini.

"Lasi sering bilang dalam hati bahwa hal itu hampir tidak mungkin. Namun sering juga keyakinannya berubah. Bila Gusti Allah berkehendak, apa pun bisa terjadi”

(BM/2005/hal:157/L/SH/M-2)

Lasi selama ini memang sangat mengharapkan bertemu dengan ayah kandungnya, namun semua itu terkadang dirasakannya sebagai hal yang tidak mungkin terjadi. Tetapi sebagai manusia yang percaya pada Tuhan, Lasi percaya kalau memang Tuhan berkehandak untuk mempertemukan semua itu mungkin saja terjadi, dan itu semua di luar kuasa manusia sebagai umat-Nya.

Sikap Hidup Tokoh Lasi dengan Diri Sendiri (Rilå "rela", Nrimå "menerima”, dan Sabar "sabar")

Setiap manusia yang menyadari bahwa dia akhirnya selalu dan seluruhya tergantung dari Yang Illahi, dengan sendirinya akan menemukan sebuah sikap yang tepat dan kematangan dalam berpikir, sehingga dapat ditanamkan dalam dirinya sebagai pedoman dalam menjalani kehidupan. Berikut kutipan tetang rasa nrimo terhadap semua keputusan.

"Masih, kang. Uang juga masih ada sedikit. Kita besok masih bisa makan. andai. kata. nira. sore. ini.terpaksa.tidak.diolah"

(BM/2005/hal:10/L/SH/N-1)

Sudah merupakan resiko sebagai seorang istri penyadap menghadapi hal yang seperti itu, nira gagal diolah karena hujan lebat yang menjadi halangan untuk mengambil dan mengolahnya. Sedikit uang sisa atau tabungan dari penjualan gula hasil olahan nira menjadi korban untuk menyambung hidup. Hal inilah yang selalu dialami Lasi sewaktu nira gagal diolah menjadi gula. Lasi tidak pernah menggerutu menghadapi semua itu karena ia telah menerima sebagai salah satu garis kehidupan dan tetap harus dijalani. Demikian juga yang dialami oleh istri para penyadap lain. Hal tersebut dapat terlihat dalam kutipan berikut ini.

"Lasi tidak perlu mempermasalahkan kesulitan hidup dan kemiskinan karena mereka tak pernah mampu melihat jalan keluar. Atau keduanya sudah diterima sebagai bagian keseharian yang sudah menyatu dan terlanjur akrab sehingga tak perlu mempertanyakannya lagi”

(BM/2005/hal:205/ L/SH/N-2)
Lasi sebagai istri seorang penyadap tidak perlu lagi mempermasalahkan segala sesuatunya mengenai kehidupan meraka. Kesulitan dan kemiskinan seolah telah akrab menjadi bagian dari kehidupan mereka, para penyadap beserta seluruh keluarganya. Mereka tidak pernah bisa melawan karena apa yang mereka inginkan tidak pernah terlihat dengan jelas jalan keluarnya. Sebagian mereka pun bahkan sudah menerimanya sebagai suratan nasib yang harus dijalani tanpa perlu pemberontakan atau protes. Selain mampu menerima segala sesuatunya, sebagai seorang istri penyadap juga harus mampu merelakan apa yang dipunyainya. Hal ini diperjelas dengan dalam data di bawah ini.

"Nanti Lasi tak boleh lagi menjual gulanya kepada pedagang lain dan harga yang diterimanya selalu lebih rendah. Malangnya bagi istri seorang penyadap, kepahitan ini masih lebih manis daripada membiarkan suami tak berdaya dan terus mengerang kesakitan”

(BM/2005/hal:25/L/SH/R-1)

Derita yang dialami Lasi masih belum sampai di sini saja ketika sang suami sedang melawan maut, karena terjatuh dari pohon kelapa yang dipanjatnya, sesuatu harus diperbuat Lasi. Kesanggupan untuk merelakan segala sesuatu yang dimilikinya pun menjadi jalan terakhir. Menggadaikan tanah satu-satunya yang menjadi sumber penghidupan kepada tauke (agen gula dari hasil olahan nira) dengan sistem yang sangat merugikan, seolah tak terasa sebagai sesuatu yang salah. Semua itu masih dirasakannya sebagai salah satu jalan terbaik, demi melihat suami tidak mengerang kesakitan. Lasi tetap bersabar dalam menghadapi semuanya karena hanya itu yang bisa dia lakukan. Hal ini terlihat pada kutipan berikut ini.

“Tidak juga. Saya kira Lasi tetap setia menemani suaminya yang bau sengak itu. Dan hal itulah yang membuat saya malah jadi lebih kasihan kepadanya. Masalahnya, apakah Lasi harus menderita lahir batin seumur hidup?”

(BM/ 2005/hal:59/L/SH/Sb-1)

Lasi tetap sabar dan setia menemani Darsa, suaminya yang sakit karena terjatuh dari pohon kelapa, sehingga syaraf Darsa di bagian pinggang robek. Hal ini membuat Darsa terus menerus mengeluarkan air seninya dan membuat bau Darsa sengak seperti orang belum mandi. Namun semua itu tidak membuat Lasi merasa risih dengan semua itu, malah dengan senang hati dia tetap menjaga dan merawat Darsa. Kesabaran dan kesetian Lasi membuat Emaknya, Mbok Wiryaji merasa kasihan 
melihat anaknya terus menerus dalam keadaan seperti ini, haruskan dia menderita lahir batin sebagai pelayan Darsa.

Sikap Hidup Tokoh Lasi dalam Kehidupan Bermasyarakat (Éthok-éthok "pura-pura”, Wedi "takut", Isin "malu", dan Sungkan "segan")

Pada dasarnya masyarakat Jawa merupakan individu yang sopan dan halus, sangat tidak menyukai keadaan yang tidak harmonis, sebisa mungkin mereka akan meredamnya supaya tidak terjadi perselisihan. Masyarakat Jawa telah menyadari bahwa dirinya sebagai individu, dengan masalah hidup, hak-hak dan kepentingan pribadi yang ada pada setiap individunya. Semua itu terbawa dalam kehidupan sehari-hari dalam berinteraksi dengan sesamanya atau dengan lingkungan masyarakat. Kondisi yang demikian membuat orang Jawa selalu membawa sikap takut, malu, segan, dan berpura-pura dalam kehidupan bermasyarakat demi menjaga karukunan. Seperti pada kutipan di bawah ini yang menggambarkan sikap berpura-pura Lasi demi menjaga perasaan Kanjat.

"Jat, aku bungah kamu menyusul aku kemari. Tetapi aku tidak mau pulang. Biarlah aku di sini. Aku ingin ngisis dari kegerahan hidupku sendiri." Tidak kasihan sama Emak? Dia kelihatan begitu menderita. Hening. Lasi menunduk dan mengusap air matanya. Tapi. itu. tak. bisa. mengubah. keputusanku. Jat!”

(BM/2005/hal:178/L/SH/Et-1)

Lasi tidak bisa menutupi rasa senang dengan kedatangan Kanjat dari kampung untuk menemuinya, walaupun tujuan Kanjat yang sebanarnya adalah ingin mengajak Lasi kembali pulang. Tapi ajakan itu langsung ditolak oleh Lasi, Lasi masih ingin menenangkan pikiranya terlebih dahulu dari segala macam cobaan dan ujian yang sedang dialaminya. Mendengar ucapan Kanjat yang mengatakan kalau Emak sangat menderita dan merana, Lasi merasa sedih dan tiba-tiba menundukkan wajahnya dan menangis karena memikirkan Emak. Setelah merasa tenang dan mantap dengan pendiriannya untuk bertahan, Lasi menolak ajakan Kanjat untuk pulang, walaupun semua itu terasa berat. Pada awalnya Lasi masih merasa segan pada Bu Lanting, karena Lasi belum mengenal Bu Lanting sepenuhnya hal ini terlihat pada kutipan di bawah ini.

"Lasi mengulurkan tangannya dengan canggung, mengucapkan terima kasih dengan suara yang hampir tak terdengar lalu melangkah masuk" (BM/2005/hal:217/L/ SH/Su-4)
Setelah dikenalkan Bu Koneng pada Bu Lanting, Lasi masih merasa segan pada tamu yang baru dikenalnya itu. Lasi tidak bisa menyembunyikan rasa segannya pada $\mathrm{Bu}$ Lanting ketika $\mathrm{Bu}$ Lanting memberinya sesuatu Lasi juga terkadang masih terlihat tegang dan kaku di depan orang yang belum dikenalnya sama sekali. Hal ini pula yang dilakukannya ketika bertemu dengan Handarbeni.

"Lasi keluar masih dengan kimono merahnya. Wajahnya merona merah ketika Handarbeni mengajaknya bersalaman setelah memujinya dengan acungan jempol” (BM/2005/hal:188/L/ SH/Su-1)

Berdasarkan kutipan di atas Lasi masih terlihat segan dengan Handarbeni, latar belakang Lasi yang dibesarkan di lingkungan desa yang selalu mengkondisikan untuk malu dan hormat kepada setiap orang yang baru dikenalnya. Membuat Lasi merasa segan kepada Handarbeni, wajahnya selalu merah merona ketika Handarbeni memujinya. Semua itu yang sangat disukai oleh Handarbeni, sikap lugu dan polos Lasi sebagai orang desa. Dari rasa malu Lasi terhadap Handarbeni, tiba-tiba muncul rasa takut pada diri Lasi. Ini bisa dilihat pada kutipan berikut ini.

"Mereka berdekat-dekatan. Lasi kembali merasa tidak seharusnya berada dalam keadaan seperti ini. Lebih lagi karena kamudian Handarbeni melingkarkan tangan pada pundaknya. Risi. Tetapi Lasi tak berani berbuat sesuatu yang mungkin bisa menyinggung perasaan Pak Han” (BM/2005/hal:222/L/ SH/W-1)

Di saat Lasi dan Handarbeni berdua-dua saja, tiba-tiba Lasi merasa hal ini tak seharusnya terjadi. Dua orang yag masih belum terikat pernikahan berdua dalam satu atap. Ditambah lagi sebuah gerakan tangan Handarbeni yang mulai perlahan melingkarkan tangannya di pundak Lasi. Menghadapi semua ini Lasi merasa risih, Lasi berperang dengan batinnya sendiri. Ingin melakukan sesuatu untuk menghindari semuanya tetapi takut tindakannya itu menyinggung Handarbeni. Rasa takut yang teramat dialami oleh Lasi juga berdampak pada rasa malunya, ini bias dilihat dari kutipan berikut ini.

"Semula Lasi hendak ikut serta, tetapi kemudian
mengurungkan niat begitu menyadari dirinya baru
sehari menjadi janda. Lasi merasa belum sanggup
hadir di tengah orang banyak; tak sanggup
menahan tatapan mata mereka" (BM/2005/hal:
254/L/SH/I-1)

Saat Emaknya Hendak keluar Lasi sebetulnya ingin ikut, akan tetapi semua itu tiba-tiba dibatalkannya sendiri. Lasi baru sadar kalau dirinya baru saja 
menjadi seorang janda, ia Malu dan tak sanggup menyandang status tersebut di depan orang banyak, sehingga setiap langkahnya pasti membuat semua mata tertuju kepadanya. Tak pelak hal ini pasti akan menimbulkan banyak pergunjingan tentang dirinya. Dalam menghadapi sebuah tekanan, suatu sikap harus diperbuat oleh lasi agar tidak menimbulkan suatu kejanggalan, berikut kutipan datanya.

"Mata Lasi basah. Darsa menunduk. Lasi melihat pongkar-ponkar teronggok di emper samping, diam dan kosong. Tungku pengolah nira, dingin dan mati. Suasana terasa gamang meskipun Kanjat, Lasi. dan. Darsa. sama-sama. berusaha. tersenyum"

(BM/2005/hal:303/L/SH/Et-2)

Sesampainya di rumah Darsa mata Lasi basah melihat semuanya, sedangkan Darsa hanya tertunduk menyambut kedatangan Lasi dan Kanjat. Mata Lasi mengamati setiap sudut rumah Darsa, dilihatnya pongkar-pongkar tergeletak di emper samping rumah, tungku tempat mengolah nira yang tak berfungsi lagi. Suasana mulai terasa berbeda meskipun semuanya mencoba tetap untuk tersenyum tapi senyum yang dipaksakan untuk menutupi segalanya, Lasi dan Kanjat sadar kalau senyum Darsa adalah senyum pembungkus pilu yang dialami dirinya, seorang penyadap yang kehilangan pekerjaannya. Sikap berpura-pura Darsa semakin menjadi-jadi tatkala Lasi mulai berbicara dengannya. Ini bisa dilihat pada kutipan berikut ini.

“Tawa Darsa meledak. Kanjat dan Lasi terpaku karena keduanya tahu, setengah kilo gula tak lebih berharga daripada setengah kilo beras” (BM/2005/hal:304/L/SH/Et-3)

Setelah berbicara dengan Lasi dan Kanjat tibatiba Darsa tertawa keras seperti orang yang tidak mempunyai beban. Lasi dan Kanjat hanya bisa terperangah menyaksikan tawa Darsa yang begitu dipaksakan, bukan hanya itu Lasi dan Kanjat juga sadar bahwa setengah kilo gula dari hasil olahan Darsa masih tidak lebih berharga dengan setengah kilo beras.

\section{Sikap Hidup Tokoh Midah dalam novel Midah Si Manis Bergigi Emas Karya Pramoedya Ananta Toer.}

\section{Sikap Hidup Tokoh Midah yang Meliputi Kehidupan Beragama (eling "ingat", pracaya "percaya", dan mituhu "percaya kepadanya")}

Walaupun telah lari dari suami dan orang tuanya, Midah masih membawa setidaknya ajaran yang telah ditanamkan oleh orang tuanya. Semua itu masih dipegang teguh oleh Midah dalam pelariannya yang jauh dari orang tua, suami dan orang-orang yang dikenalnya. Hal ini setidaknya terlihat dalam kutipan berikut ini.

"Ia banyak mendengar cerita tentang kemesuman
di hotel-hotel. Karena itu tidak henti-hentinya ia
mendoa. Tiap kali ia dengar langkah kaki di
depan pintunya ia mencepatkan doanya. Dan
waktu tak tertahankan lagi kantuknya, ia tepuk
perutnya lambat-lambat, berbisik: Dihindarkanlah
engkau hendaknya dari segala bencana ia ulangi
bisikannya itu untuk mem-peroleh keyakinan lebih
banyak"
(MSBE/2009/hal:28/M/SH/M-1)

Midah merasa cemas dengan banyaknya cerita yang dia dengar tentang hal yang sering terjadi di tempatnya menginap sekarang. Hal ini membuat Midah selalu berdoa dan meminta keselamatan kepada Tuhan. Setiap Derap kaki yang melangkah di depan pintu kamarnya terdengar ia lebih cepat memanjatkan doanya kepada Tuhan. Semua itu terus berulang sampai saat matanya tidak sanggup lagi untuk menahan kantuk yang sudah menyarang. Perlahan dia mulai merebahkan badanya dan merabah perutnya untuk memberikan keyakinan pada dirinya sendiri dan anak yang ada di dalam perutnya sampai ia tertidur. Rasa percaya pada Tuhannya membuat Mida merasa tenang dan mudah dalam menjalani kehidupannya pada saat pelarian. Ini bisa dibuktikan dengan kutipan berikut ini.

"Jangan dengarkan dia, orang itu menasehati Midah, mau engkau ikut rombongan? Midah mengangguk, dan dalam hatinya bersyukur kepada.Tuhan bapaknya.juga"

(MSBE/2009/hal:33/M./SH/El-2)

Setelah saling berbicara, tiba-tiba terdengar suara yang menawarkan untuk bergabung dengan rombongan. Tanpa berpikir panjang Midah mengangguk untuk mengiyakan ajakan tersebut. Tak lupa dalam hatinya ia mengucapkan rasa syukur kepada Tuhan yang telah memberikan semua itu kepadanya, dan tentunya Tuhan yang disembah oleh bapaknya juga. Rasa percaya itu selalu ia wujudkan dalam bentuk perbuatan untuk menghadapi segala kejadian dalam hidupnya, kutipan data berikut ini buktinya.

"Ia mengucapkan syukur. Ia melahirkan tanpa pertolongan siapapun jua. Dan barulah datang bidan mengambil anak itu setelah menyelesaikan pusat. Anak itu diambil oleh bidan dan dimandikan. Ia dengar anaknya menangis, begitu sehat, begitu keras, air matanya kembali mengalir" (MBSE/ 2009/hal:50/M/SH/El-1) 
Rasa syukur itu kembali ia ucapkan kepada Tuhan, semua ini karena kehendaknya. Ia melahirkan anak yang selama ini yang begitu dijaganya tanpa pertolongan siapa pun, termasuk bidan yang ada di rumah sakit itu. dan barulah bidan itu datang untuk membantu menyelesaikan pusat dan mengambil anaknya untuk dimandikan. Kemudian ia mendengar tangisan anaknya, ia mencoba untuk melihatnya begitu keras suara tangisan dan anaknya terlihat begitu sehat. Tanpa terasa ia kembali menitihkan air matanya. Rasa syukur itu kembali membuatnya tegar terhadap segala ujian, karena Midah percaya Tuhan selalu ada di sampingnya. Ini dibuktikan dengan kutipan berikut ini.

"Ia tak merasa adanya rasa sakit hati oleh olokan itu. Ia rasai kebebasan pantun yang segera mengena di perasaannya. Tangannya diangkatnya dari meja dan diturunkan di atas perutnya. Pada anak di bawah jantung itu ia mencari kekuatan dan keimanan"

(MSBE/2009/hal:31/M/SH/P-1)

Setelah merasa bisa diterima dalam rombongan, Midah tidak lagi menghiraukan segala macam olokan yang ditujukan kepadanya. Bahkan sebaliknya, ia merasa ada kebebasan dalam bermain pantun yang mengena pada perasaanya. Tak lama kemudaian perlahan tangannya diangakat dari meja, diraba perutnya yang sedang mengandung. Dalam hati ia mencari kekuatan dan keimanan pada anaknya yang selama ini telah menjaga dia dari segala macam perbuatan yang tercela. Dan sampai saat perutnya merasasakit dan tak tertahankan lagi Midah pergi ke Puskesmas, seperti pada kutipan berikut ini.

"Ada ia rasa perutnya pecah dan anaknya akan datang. Ia berzikir. Dalam zikir ia minta ampun pada Tuhannya, pada dua orangtuanya, juga pada suaminya"

(MBSE/ 2009/hal:50/M/SH/M-6)

Ketika anaknya akan lahir, ia merasakan perutnya pecah dan sakit yang tak terkira. Midah mencoba berzikir pada Tuhan dan meminta ampun atas apa yang selama ini dilakukannya. Midah meminta maaf pada Tuhannya, pada kedua orang tuanya, dan pada suaminya yang telah ia tinggalkan. Midah terus berdoa dan memohon pada Tuhannya agar diberikan anak yang tidak cacat satupun dan kelak anaknya bisa menjadi orang yang bebas menentukan pilihannya sendiri. Dalam doanya Midah juga berharap Tuhan akan memberikan kehidupan yang lebih baik pada anaknya. Ini bias dilihat pada kutipan berikut ini.

"Ia tetap berdoa dan memohon agar anaknya kelak dapat berbuat sekehendak hatinya tanpa halingan dari siapapun yang tidak menyetujuinya. Dan agar anaknya hidup bahagia terlepas dari tindasan orang lain”

(MBSE/2009/ hal:48/M/SH/M-2)

Midah tetap memanjatkan doa kepada Tuhan, supaya kelak anaknya dapat melakukan segala sesuatu yang ia inginkan tanpa ada halangan dan rintangan. Bebas dari segala macam bentuk penindasan dari orang lain, dan hidup bahagia. Bukan seperti yang dialami oleh Midah selama ini, menderita dan tertindas oleh orang lain. Diulanginya terus menerus doa itu pada Tuhannya. Seperti pada kutipan berikut ini.

"Midah terus memohon pada Tuhannya agar selalu selamat, agar anak. yang dikandungnya. tidak. diganggu.oleh.siapapun"

(MBSE/2009/hal:43/M/SH/M-5)

Dikala semua rombongan masih sibuk dengan apa yang akan dilakukannya esok, Midah berdoa dan memohon pada Tuhannya, agar selalu dilindungi dan diberikan keselamatan untuk dirinya dan juga anak yang dikandungnya itu. Setelah anaknya lahir Midah mulai tersisih di kelompoknya, dengan berat hati Midah mencoba untuk meninggalkan kelompok musik keliling itu dan memulai segalanya dengan yang baru.

Sikap Hidup Tokoh Midah dengan Diri Sendiri (Rilå “rela”, Nrimå “menerima”, dan Sabar "sabar")

Dalam kondisi berbadan dua Midah merasa sudah tak mampu lagi untuk berjalan dan menyanyi bersama rombongan musik keroncong. Ia ingin sejenak berhenti dan menaruh semua beban yang dirasakannya, hal ini bisa dilihat dari kutipan berikut ini.

“Aku mengerti juga, Manis. Tetapi engkau harus pula ingat, tiada bekerja engkau pun tiada menerima nafkah. Berita itu menggoncangkan hati Midah. Ia tidak menyangka akan terjadi demikian. Namun ia lebih memihak kepada anaknya, karena itu disampaikannya juga: Biarlah. Tapi toh aku usahakan agar engkau tetap menerima nafkah sekalipun tidak mungkin sebanyak yang bisa engkau terima” (MSBE/2009 /hal:46/M/SH/N-1)

Kondisi tubuhnya yang sudah tidak bisa diajak berjalan jauh lagi membuat Midah tidak ikut bekerja dengan rombongan. Semua itu mebuatnya tidak mendapatkan nafkah lagi untuk simpanan biaya persalinan anaknya. Seperti yang diucapkan oleh kepala rombongan, mendengar semua itu hati midah merasa tidak bisa menerimanya dan kenapa semuanya 
bisa terjadi kepada dirinya. Akan tetapi kemudian ia menerimanya tanpa banyak protes. Kondisi itu mebuat kepala rombongan merasa iba dan akan mengusahakan tetap ada nafkah untuk Midah walaupun tidak seperti yang diterima sebelumnya. Apapun tetap Midah usahakan agar anak yang dikandungnya tetap sehat termasuk dengan menerima berapapun rezekinya hari ini. Hal ini bisa dilihat pada kutipan data berikut.

"Ia menyanyi di depot-depot. Ia pergunakan senyum pemikat sebaik-baiknya. Kadang-kadang ia menyanyi dari rumah ke rumah dan lebih banyak diusir daripada menerima rezeki” (MSBE/ 2009/ hal:77/M/SH/N-2)

Setelah memutuskan untuk meninggalkan rombongan yang selama ini memberinya nafkah. Midah mulai bernyanyi sendirian, di depot-depot, di tempattempat keramaian. Sesekali ia gunakan senyuman untuk memikat para pendengarnya. Setelah menyanyi dari depot-depot ia menyanyi dari rumah ke rumah, semunya itu ia lakukan demi memenuhi kebutuhan hidupnya. Tak jarang ia lebih sering diusir dari pada mendaptkan rizki ketika menyanyi, namun ia tetap menerima semua itu, dan tetap tidak putus asa.

Sikap Hidup Tokoh Midah dalam Kehidupan Bermasyarakat (Éthok-éthok "pura-pura”, Wedi "takut”, Isin "malu”, dan Sungkan "segan”)

Sebagai seorang wanita, Midah juga memiliki rasa takut dalam dirinya. Walapun tengah asik mengikuti rombongan grup musik keroncong yang sedari tadi ia amati dari kejauhan, hal ini bisa dilihat dari kutipan berikut ini.

"Ia terus mengikuti, dari Kampung Duri hingga Glodok dan dari Glodok ke Pasar Baru. Waktu matahari telah tenggelam, baru ia merasa takut pada orang tuanya. Segera ia melompat ke atas trem dan pulang ke rumah"

(MBSE/2009/hal:17/M/SH/W-1)

Midah terus mengikuti rombongan grup musik keroncong itu, ke mana pun grup itu pergi Midah tetap mengikutinya, mulai dari satu tempat ke tempat lain terus ia ikuti. Tanpa ia sadari waktu akan menginjak malam hari, ia cepat-cepat melangkah pulang karena takut akan kedua orang tuanya, terlebih pada bapaknya. Akibat semua ulahnya itu Midah membuat bapaknya marah besar kepadanya dan melakukan sesuatu yang tidak pernah ia dapatkan selama ini. Seperti pada kutipan di bawah ini.

"Kekagetan lebih terasa padanya daripada kesakitan. Ia pandangi bapaknya yang bermata merah di depannya, kemudian dengan ketakutan ia bangun. Ia menangis perlahan. Dan waktu melihat dilihat mata bapaknya masih mendelikinya, ia menjerit ketakutan”

(MSBE/2009/hal:18/M/SH/W-2)

Midah tidak merasakan sakit karena tamparan bapaknya, tapi yang labih ia rasakan adalah rasa terkejut. Terkejut dengan apa yang telah diperbuat oleh bapaknya. Setalah itu ia pandangi mata bapaknya yang sedang berdiri di depannya. Ia bangun dan menangis. Dipandangi lagi bapaknya yang masih memelototinya, kemudian ia lari dan menjerit ketakutan dan mencari perlindungan. Bukan hanya kejadian itu saja yang ditakutinya, tapi sosok bapaknya yang sudah berubah semanjak Midah tumbuh dewasa, ini bias dibuktikan dengan kutipan berikut ini.

"Dan juga yang lebih hebat dari pada itu: ia takut pada bapaknya. Bapak yang beberapa tahun yang lalu masih membelai-belai pipinya di kursi goyang sambil mendengarkan Umi Kalsum” (MSBE/ 2009/hal:20/M/SH/W-3)

Pada kutipan di atas dijelaskan bahwa Midah merasa takut dengan sosok bapak yang dulu begitu mencintainya dan menyayanginya, tapi kini sosok tersebut telah berubah menjadi sosok yang menakutkan baginya. Belum hilang rasa takut Midah pada bapaknya, kini ia dirudung rasa malu akan sesuatu hal yang telah diperbuatnya, ini bisa dilihat dari kutipan berikut ini.

"Beberapa hari itu ia mengurung diri di dalam kamarnya. Ia malu pada emaknya. Ia malu pada tetangganya. Ia malu pada segala-galanya” (MSBE/2009/hal:19/M/SH/I-1)

Karena kejadian itu ia mulai mengurung dirinya di dalam kamar. Midah merasa malu kepada emaknya. Malu kepada para tetangga karena tidak bisa menuruti perintah bapaknya. Dan malu kepada semuanya. Malu karena tidak bisa menjadi seperti yang dinginkan oleh kedua orangtuanya. Belum lepas rasa malunya pada bapaknya Midah Juga menyimpan rasa sungkan terhadap seorang pria yang juga baru ia kenal, ini bias dilihat dari kutipan berikut ini.

"Polisi itu tidak menghiraukan pandangan orangorang lain. Tidakkah malu makan di dekatku? Tanya midah. Malu? Mengapa malu? Keramahannya itu melenyapkan kemalu-maluan Midah terhadapnya"

(MBSE/2009/hal:78/M/SH/Su-1)

Ketika sedang makan dengan seorang polisi, Midah merasa malu. Malu karena tak sepantasnya seorang polisi makan bersama dengan seorang penyanyi keroncong jalanan. Berkali-kali Midah 
melontarkan pertanyaan kepada polisi tersebut, apakah tidak malu makan bersama saya? Sikap yang ramah dan bersahabat yang ditunjukkan oleh polisi tersebut seketika membuat rasa malu Midah berangsur-angsur hilang dan merasa tidak ada jarak lagi di antara mereka berdua.

\section{KESIMPULAN}

Sikap hidup Midah sebagai wanita Jawa mencerminkan pandangan hidupnya yang masih tetap berpegang pada ajaran agama dan tatanan nilai pada masyarakat, walaupun Midah hidupnya lebih bebas dan jauh dari kontrol orang tua. Midah masih tetap ingat akan ajaran kedua orang tuanya sewaktu ia kecil. Jadi di mana pun ia berada, ia tetap berpegang teguh pada ajaran tersebut, sehingga sikap hidupnya pun tak jauh dari ajaran yang selama ini dipahaminya.

Sikap hidup Lasi juga mencerminkan dari pandangan hidupnya yang masih tetap berpegang pada ajaran agama dan nilai-nilai pada masyarakat, walaupun Lasi memilih untuk melarikan diri dari desanya dan tinggal di Jakarta, yang notabene kehidupannya lebih berbeda dengan kehidupan Lasi di desa yang lebih guyup. Derap kehidupan Jakarta ternyata tidak pernah melunturkan sikap hidup Lasi sebagai sosok wanita Jawa seperti halnya konsep wanita Jawa yang lemah lembut dan menjadi abdi bagi suaminya masih dipegang teguh olehnya, walaupun terkadang Lasi merasa masih terkungkung oleh segala aturan tersebut.

Berdasarkan hasil penelitian, dapat disimpulkan bahwa sosok wanita Jawa yang tercermin dalam novel Midah Si Manis Bergigi Emas karya Pramoedya Ananta Toer adalah wanita yang bebas dan mandiri serta masih tetap berpegang teguh pada ajaran agama dan nilai-nilai pada masyarakat. Adapun sosok wanita Jawa dalam novel Bekisar Merah karya Ahmad Tohari tercermin sebagai wanita yang tidak merasa bahagia dan belum bebas menjalankan kehidupannya. Selain itu, masih berperan dalam sektor domestik.

\section{DAFTAR PUSTAKA}

Alwi, Hasan. 2001. Kamus Besar Bahasa Indonesia. Ed. III. Jakarta: Depdiknas RI dan Balai Pustaka.

Faruk, H.T. 1999. Pengantar Sosiologi Sastra. Yogyakarta: Pustaka Pelajar.

Koentjaraningrat. 1984. Kebudayaan Jawa. Jakarta: PT Balai Pustaka.

Mulder, Niels. 1996. Pribadi dan Masyarakat Di Jawa. Jakarta: Pustaka Sinar Harapan.
Pradopo, Rahmad Djoko. 1990. Pengkajian Puisi. Yogyakarta: Gadjah Mada University Press.

Semi, Atar. 1989. Kritik Sastra. Bandung: Angkasa. Suseno, Franz Magnis. 1987. Etika Jawa. Jakarta. PT. Gramedia Pustaka Utama.

Toer, Pramoedya Ananta. 2003. Midah Si Manis Bergigi Emas. Jakarta: Lentera Dipantara.

Tohari, Ahmad. 2005. Bekisar Merah. Jakarta: PT. Gramedia Pustaka 